\title{
Use of a Common Standard for Comparison of Insulin C-peptide Measurements by Different Laboratories
}

\author{
C. P. J. Caygill, R. E. Gaines Das, and D. R. Bangham \\ National Institute for Biological Standards and Control, Hampstead, London, England
}

\begin{abstract}
Summary. A synthetic human C-peptide analogue has been used as a common standard for the comparison of insulin C-peptide measurements in seven assay systems in six laboratories. Even in terms of this common standard there was statistically significant numerical heterogeneity between laboratories for estimates of the C-peptide content of the same plasma samples. However, the consistency in ranking order of estimates of C-peptide in the plasma samples between laboratories suggests that laboratories are in most cases measuring at least similar immunoreactive constituents and that a reference plasma might prove useful in comparing results between laboratories. Until a more suitable reference material is available, the synthetic analogue, 64 formyllysine C-peptide, in ampoules coded 76/561, will be made available for research purposes.
\end{abstract}

Key words: Standard, C-peptide of proinsulin, human proinsulin, radioimmunoassay, insulin, diabetes.

It has been shown in normal subjects that there is a close correlation of C-peptide and insulin levels in plasma, and thus estimates of $\mathrm{C}$-peptide concentration can be used as a guide to $\beta$-cell function. This may be useful in insulin-treated diabetics in whom circulating antibodies to injected insulin interfere with measurements of endogenous insulin [1]. The use of C-peptide measurement and its diagnostic application has been investigated by many workers $[2,3,4,5]$. Obviously a reference preparation for use in immunoassays of human C-peptide is necessary for valid comparison of estimates from different laboratories. The Expert Committee on Biological Standardization (26th Report, WHO Technical Report Series No. 565, 1975) asked the National
Institute for Biological Standards and Control to collect information on the feasibility of setting up such a reference preparation. A suitable quantity of human C-peptide was not however available. The only material available in sufficient quantity was synthetic 64formyllysine C-peptide which includes the extra four basic amino acids (two at each end) of the normal proinsulin sequence. The presence of formyllysine in position 64 is reported to improve stability and solubility in aqueous solution. This paper reports an international collaborative study of the use of this material (in ampoules coded 76/561) for immunoassays of C-peptide in human plasma.

\section{Materials and Methods}

\section{Participants}

The six participants in the collaborative study are listed below. Throughout the report each is identified by a number which is not the same as the order of listing.

Professor C.N. Hales, Department of Medical Biochemistry, Welsh National School of Medicine, Heath Park, Cardiff, CF4 4XN, Wales.

Dr. Lise G. Heding, Novo Research Institute, Novo Alle, DK2880 Bagsvaerd, Denmark.

Dr. A. Matsuda and Dr. T. Kuzuya, Jichi Medical School, Minamikawachi-Machi, Tochigi-Ken, Japan 329-04.

Dr. A. Rubenstein and Dr. D. L. Horwitz, Department of Medicine and Dr. D. Steiner, Department of Biochemistry, The University of Chicago, 950 East 59th St., Chicago, Illinois 60637, USA.

Dr. R. C. Turner, Nuffield Department of Clinical Medicine, The Radcliffe Infirmary, Oxford OX2 6HE, England.

Professor N. Yanaihara, Shizuoka College of Pharmacy, 2-2-1 Oshika, Shizuoka-shi, Japan. 
Table 1. Preparations examined in the collaborative study

\begin{tabular}{|c|c|c|}
\hline $\begin{array}{l}\text { Ampoule } \\
\text { marking for } \\
\text { collabora- } \\
\text { tive study }\end{array}$ & $\begin{array}{l}\text { NIBSC } \\
\text { code no. }\end{array}$ & Description \\
\hline $76 / 561$ & $76 / 561$ & $\begin{array}{l}\text { Research Standard. Synthetic (64-for- } \\
\text { myllysine-) human proinsulin 31-65 }\end{array}$ \\
\hline A & $76 / 561$ & $\begin{array}{l}\text { Ampoule identical to } 76 / 561 \text { except } \\
\text { code labelled }\end{array}$ \\
\hline \multirow[t]{2}{*}{$66 / 304$} & $66 / 304$ & $\begin{array}{l}\text { 1st International reference } \\
\text { preparation of human insulin for } \\
\text { immunoassay }\end{array}$ \\
\hline & & $\begin{array}{l}\text { Freeze dried residue of } 1.5 \mathrm{ml} \text { plasma } \\
\text { from: }\end{array}$ \\
\hline Z & $77 / 517$ & A patient with insulinoma \\
\hline $\mathrm{F}$ & $77 / 518$ & A patient with insulinoma \\
\hline $\mathrm{H}$ & $77 / 535$ & $\begin{array}{l}\text { A } 52 \text { year old with diabetes for } 15 \\
\text { years }\end{array}$ \\
\hline $\mathrm{R}$ & $77 / 537$ & $\begin{array}{l}\text { A } 45 \text { year old with diabetes for } 2 \text { years } \\
\text { and recovering from severe } \\
\text { ketoacidosis }\end{array}$ \\
\hline $\mathrm{X}$ & $77 / 516$ & $\begin{array}{l}\text { A pool of plasma from } 4 \text { healthy sub- } \\
\text { jects } 1.5 \mathrm{~h} \text { after ingestion of } 50 \mathrm{~g} \text { of } \\
\text { glucose }\end{array}$ \\
\hline $\mathbf{M}$ & $77 / 541$ & A single subject after an overnight fast \\
\hline B & $77 / 539$ & $\begin{array}{l}\text { Same subject as M, } 1.5 \mathrm{~h} \text { after inges- } \\
\text { tion of } 50 \mathrm{~g} \text { of glucose }\end{array}$ \\
\hline $\mathrm{T}$ & $77 / 543$ & $\begin{array}{l}\text { A mixture of equal parts of plasmas } M \\
\text { and } B\end{array}$ \\
\hline
\end{tabular}

\section{Research Standard of Synthetic 64-formyllysine $C$-peptide of Human Proinsulin}

The Research Standard comprises a batch of some 450 capillary ampoules coded $76 / 561$ each containing the freeze-dried residue of approximately $10 \mu \mathrm{g}$ (64-formyllysine) human proinsulin $31-65,50 \mu \mathrm{g}$ human albumin and $0.05 \mathrm{~mol} / \mathrm{l} \mathrm{Na-phosphate} \mathrm{buffer,}$ $\mathrm{pH} 7.4$.

\section{Preparation of Ampoules}

A quantity of synthetic 64-formyllysine human proinsulin 31-65 (batch no. NY-CY-7-55-2) together with the following information was generously provided by Professor N. Yanaihara:

\begin{tabular}{llll} 
Elemental Analysis: Calculated for $\mathrm{C}_{154} \mathrm{H}_{259} \mathrm{~N}_{49} \mathrm{O}_{53}$ \\
\multicolumn{4}{c}{$4 \mathrm{CH}_{3} \mathrm{CO}_{2} \mathrm{H}_{17} .17 \mathrm{H}_{2} \mathrm{O}$} \\
Theoretical & $\mathrm{C} 46.4 \%$ & $\mathrm{H} 7.43 \%$ & $\mathrm{~N} 16.4 \%$ \\
found & $\mathrm{C} 46.0 \%$ & $\mathrm{H} 6.96 \%$ & $\mathrm{~N} 16.7 \%$
\end{tabular}

Amino Acid Analysis: In hydrolysate with $6 \mathrm{~mol} / \mathrm{L} \mathrm{HCl}$, $110^{\circ}, 48 \mathrm{~h}$

$\begin{array}{lllllll}\text { Theoretical } & \text { Asp 1 } & \text { Ser 2 } & \text { Glu 8 } & \text { Pro 2 } & \text { Gly 7 } & \\ \text { found } & 0.96 & 1.68 & 7.93 & 1.92 & 7.35 & \\ \text { Theoretical } & \text { Ala 3 } & \text { Val 2 } & \text { Leu 6 } & \text { Lys 1 } & \text { Arg 3 } & \mathrm{NH}_{3} 5 \\ \text { found } & 3.01 & 1.97 & 6.05 & 0.95 & 2.83 & 4.86\end{array}$

Peptide Content $89 \%$

Optical Rotation $(\alpha)_{\mathrm{D}} 29=-96.9^{\circ}(\mathrm{c} 0.58,10 \%$ acetic acid)
Thin Layer Chromatography

RF 0.11 (1-butanol-acetic acid- $\mathrm{H}_{2} \mathrm{O}, 4: 1: 5$ )

RF 0.35 (1-butanol-pyridine-acetic acid- $\mathrm{H}_{2} \mathrm{O}, 30: 20: 6: 24$ )

On receipt at the National Institute for Biological Standards the bulk material was stored in a sealed bottle as received, at $-20^{\circ}$ with silica gel desiccant. It was allowed to warm up to room temperature and $6.3 \mathrm{mg}$ dissolved in $6.3 \mathrm{ml}$ sterile $0.05 \mathrm{~mol} / 1 \mathrm{Na}$-phosphate buffer $\mathrm{pH} 7.4$ containing $0.05 \mathrm{ml} / \mathrm{ml}$ of a $100 \mathrm{~g} / \mathrm{l}$ solution of human albumin (batch no. AK3, Lister Institute, Elstree), free of peptidase [6]. The final solution was centrifuged for $10 \mathrm{~min}$ at $1000 \mathrm{~g}$ at $4^{\circ}$. All manipulations of the material were carried out at $4^{\circ}$. The solution was distributed in $10 \mu \mathrm{g}$ (range $\pm 2.1 \%$ ) portions by weight into 500 siliconized neutral glass capillary ampoules. These portions were shelf frozen, then freeze-dried. After secondary desiccation to constant weight, the ampoules were filled with pure dry nitrogen and sealed by fusion of the glass. Results of tests on a trial fill showed that both the frozen material (no carrier present) and the freeze-dried material ampouled without carrier albumin migrated as a single band on polyacrylamide gel electrophoresis at $\mathrm{pH} 8.5$ somewhat more slowly than insulin. This pattern was not altered after an ampoule of the freeze-dried material had been stored at $45^{\circ}$ for 21 days.

\section{Design of the Study, Assay Systems Used and Preparations Examined}

The preparations examined in the study are listed in Table 1. Of these, the identities of only the Research Standard and the International Reference Preparation of human insulin, included to detect any cross-reactivity, were known to the participants. The ampoules coded $\mathrm{A}$ were described to the participants as containing approximately $10 \mu \mathrm{g}$ of human insulin C-peptide and $50 \mu \mathrm{g}$ human albumin but the identity with the Research Standard was not disclosed. The ampoules of freeze-dried residue of plasma samples were coded by letter and described to the participants as being variously from patients with insulinoma or diabetes or normal individuals before or after oral glucose. In addition to these preparations each laboratory was asked to include its own local standard (Table 2). Participants were requested to use their usual assay procedure except that the Research Standard, the ampoules coded $A$ and the local standard were to be included at as many dilutions as practicable (preferably not less than five) and the plasma preparations at preferably two or more dilutions. Each participant carried out two independent radioimmunoassays using the methods and reagents listed in Table 2 except Laboratory 3 which carried out four assays, two assays with each of two antisera. These assays using different antisera have been treated as separate assay methods. Laboratory 6 also carried out two radioimmunoassays for insulin. Laboratory 2 removed proinsulin-like components prior to assay using a solid phase insulin antibody immunoadsorbent. Laboratory 6 removed proinsulin and insulin prior to assay using sepharose bound antibody, and also extracted insulin antibodies from samples $\mathrm{H}$ and $\mathrm{R}$ prior to assay.

\section{Statistical Analysis}

For each radioimmunoassay, the responses (counts or percent bound) were transformed to logits using asymptotic values for maximum and non-specific binding chosen to give linearity of log dose-logit response lines [7]. The data were then analysed as multiple parallel line assays using weighted linear regression. Analysis of variance, in which allowance is made for the number of dilutions of each preparation included in the assay, was performed for each multiple assay and the assumptions of linearity and parallelism were tested at the $1 \%$ significance level. Mean potency estimates 
Table 2. Radioimmunoassay systems used in the collaborative study

\begin{tabular}{|c|c|c|c|c|c|c|}
\hline Laboratory & Local standard & Antiserum & $\begin{array}{l}\text { Reputed cross- } \\
\text { reactivity of } \\
\text { system }\end{array}$ & $\begin{array}{l}\text { Iodinated } \\
\text { C-peptide }\end{array}$ & $\begin{array}{l}\text { Separation of } \\
\text { bound from free }\end{array}$ & $\begin{array}{l}\text { Dose range of local } \\
\text { standard studied. } \\
\text { Mass/ml solution }\end{array}$ \\
\hline 1 & $\begin{array}{l}\text { (64-formyllysine) } \\
\text { proinsulin 31-65 }\end{array}$ & $\begin{array}{l}\text { Against (64-for- } \\
\text { myllysine) proin- } \\
\text { sulin 31-65 }\end{array}$ & $\begin{array}{l}\text { Insulin: } 0 \\
\text { Proinsulin: } 15 \% \\
\text { according to sup- } \\
\text { plier }\end{array}$ & $\begin{array}{l}\text { Tyrosylated at } \\
\text { Arg. } 31 \text {; lac- } \\
\text { toperoxidase iodi- } \\
\text { nation with } \mathbf{I}^{125}\end{array}$ & $\begin{array}{l}\text { Double anti- } \\
\text { body }\end{array}$ & $\begin{array}{l}0.195-3.13 \mathrm{ng} \\
(0.05-0.81 \mathrm{pmol})^{\mathrm{a}}\end{array}$ \\
\hline 2 & $\begin{array}{l}\text { From Novo (batch } \\
\text { 2). Synthetic proin- } \\
\text { sulin 33-63 from } \\
\text { Dr. Naithani }\end{array}$ & $\begin{array}{l}\text { M1187 from } \\
\text { Novo. Against } \\
\text { synthetic proinsu- } \\
\text { lin } 33-63 \text { coupled } \\
\text { to Albumin }\end{array}$ & $\begin{array}{l}\text { Insulin: } 0 \\
\text { Proinsulin: not } \\
\text { tested }\end{array}$ & $\begin{array}{l}\mathrm{I}^{125}-\mathrm{Tyr}-\mathrm{C}-\text { pep- } \\
\text { tide from Novo }\end{array}$ & $\begin{array}{l}\text { Double anti- } \\
\text { body }\end{array}$ & $0.05-1.25 \mathrm{pmol}$ \\
\hline $\begin{array}{l}3 \\
\text { Antiserum } \\
\text { A }\end{array}$ & $\begin{array}{l}\text { Endogenous human } \\
\text { C-peptide obtained } \\
\text { from pancreas post- } \\
\text { mortem }\end{array}$ & $\begin{array}{l}\text { Ab-1 against } \\
\text { synthetic (64-for- } \\
\text { myllysine) proin- } \\
\text { sulin 31-65 from } \\
\text { Prof. Yanaihara }\end{array}$ & $\begin{array}{l}\text { Insulin: } 0 \\
\text { Proinsulin: } 33 \%\end{array}$ & $\begin{array}{l}\text { Tyrosylated } \\
\text { C-peptide iodi- } \\
\text { nated using } \\
\text { chloramine-T }\end{array}$ & $\begin{array}{l}\text { Double anti- } \\
\text { body }\end{array}$ & $\begin{array}{l}0.025-20 \mathrm{ng} \\
(0.01-6.67 \mathrm{pmol})^{\mathrm{b}}\end{array}$ \\
\hline $\begin{array}{l}3 \\
\text { Antiserum } \\
\text { B }\end{array}$ & $\begin{array}{l}\text { Endogenous human } \\
\text { C-peptide obtained } \\
\text { from pancreas post- } \\
\text { mortem }\end{array}$ & $\begin{array}{l}\text { Ab-2 against } \\
\text { synthetic (64-for- } \\
\text { myllysine) proin- } \\
\text { sulin 31-65 from } \\
\text { Prof. Yanaihara }\end{array}$ & $\begin{array}{l}\text { Insulin: } 0 \\
\text { Proinsulin: } 33 \%\end{array}$ & $\begin{array}{l}\text { Tyrosylated } \\
\text { C-peptide iodi- } \\
\text { nated using } \\
\text { chloramine-T }\end{array}$ & $\begin{array}{l}\text { Double anti- } \\
\text { body }\end{array}$ & $\begin{array}{l}0.025-20 \mathrm{ng} \\
(0.01-6.67 \\
\text { pmol }^{\mathrm{b}}\end{array}$ \\
\hline 4 & $\begin{array}{l}\text { From Novo. Syn- } \\
\text { thetic proinsulin } \\
\text { 33-63 from } \\
\text { Dr. Naithani }\end{array}$ & $\begin{array}{l}\text { M1230 from } \\
\text { Novo. Against } \\
\text { synthetic proinsu- } \\
\text { lin 33-63 }\end{array}$ & $\begin{array}{l}\text { Insulin: } 0 \\
\text { Proinsulin: } 35 \%\end{array}$ & $\begin{array}{l}\mathrm{I}^{125} \text {-Tyr-C-pep- } \\
\text { tide from Novo }\end{array}$ & Charcoal & $0.1-2 \mathrm{pmol}$ \\
\hline 5 & $\begin{array}{l}\text { (64-formyllysine) } \\
\text { proinsulin 31-65 }\end{array}$ & $\begin{array}{l}\text { Against (64-for- } \\
\text { myllysine) proin- } \\
\text { sulin 31-65 }\end{array}$ & $\begin{array}{l}\text { Insulin: } 0 \\
\text { Proinsulin: } 35 \%\end{array}$ & $\begin{array}{l}\mathrm{N}^{2} \text {-Tyrosylated } \\
\text { (64-formyllysine) } \\
\text { proinsulin 31-65 }\end{array}$ & $\begin{array}{l}\text { Double anti- } \\
\text { body }\end{array}$ & $\begin{array}{l}0.195-50 \mathrm{ng} \\
(0.05-13 \mathrm{pmol})^{\mathrm{a}}\end{array}$ \\
\hline 6 & $\begin{array}{l}\text { Synthetic proinsulin } \\
\text { 33-63 from } \\
\text { Dr. Naithani }\end{array}$ & $\begin{array}{l}\text { M1181 against } \\
\text { crude proinsulin }\end{array}$ & $\begin{array}{l}\text { Insulin: } 0 \\
\text { Proinsulin: } 30 \%\end{array}$ & $\begin{array}{l}\text { Synthetic proinsu- } \\
\text { lin 33--63 Tyro- } \\
\text { sylated and iodi- } \\
\text { nated with } \mathrm{I}^{125}\end{array}$ & Ethanol & $0.05-1.0 \mathrm{pmol}$ \\
\hline
\end{tabular}

a Assumed molecular weight 3800

b Assumed molecular weight 3000

were computed using the logarithms of the potency estimates and confidence intervals about the means were based on the variability among the logarithms of the potency estimates which were combined to give the mean.

\section{Results}

\section{Log Dose-Logit Response Relationships}

The log dose-logit response lines were generally linear except for a few instances of curvature near the ends of an extended response range (counts outside the range $10 \%-90 \%$ of maximum binding corrected for non-specific binding) (Fig. 1 and 2). The responses to the doses examined for the 1st International Reference Preparation of Human Insulin were in all cases greater than $90 \%$ of maximum binding and results with this preparation were deleted from further analysis.

The slopes of the log dose-logit response lines are given in Table 3. Examination of the slopes for the Research Standard, the preparation labelled A (identical to the Research Standard), and the local standard of insulin C-peptide supported the conclusion that, except in the assay systems of Laboratories 4, and 3 using Antiserum B, the dose response lines for the Research Standard and the local standard were parallel. Figure 1 illustrates the parallel dose response lines of Assay 2, Laboratory 5. Figure 2 illustrates the non-parallel lines of Assay 2, Laboratory 4 . The plasma samples were assayed at three dilutions except in Laboratory 6 and in some cases the responses to one or more dilutions were near the limits of the response range. Thus the estimates of 
Table 3. Slopes of log dose-logit response lines. Numbers in brackets give the number of dilutions for the standard curves. Slopes of plasma samples are based on three dilutions except for Laboratory 6 Assay 2 which used one $\left({ }^{*}\right)$ or two dilutions

\begin{tabular}{|c|c|c|c|c|c|c|c|c|c|c|c|c|}
\hline \multirow[t]{2}{*}{ Laboratory } & \multirow[t]{2}{*}{ Assay } & \multicolumn{3}{|c|}{ Insulin C-peptide } & \multicolumn{8}{|c|}{ Plasma sample } \\
\hline & & $76 / 561$ & A & Local & $\mathrm{H}$ & $\mathrm{R}$ & $X$ & B & $\mathrm{T}$ & $\mathrm{M}$ & $\mathrm{Z}$ & $\mathrm{F}$ \\
\hline 1 & $\begin{array}{l}1 \\
2\end{array}$ & $\begin{array}{l}-0.78(5) \\
-0.84(6)\end{array}$ & $\begin{array}{l}-0.78(6) \\
-0.92(6)\end{array}$ & $\begin{array}{l}-0.81(9) \\
-1.06(9)\end{array}$ & $*$ & $\begin{array}{l}-0.89 \\
-0.91\end{array}$ & $\begin{array}{l}-0.74 \\
-0.76\end{array}$ & $\begin{array}{l}-0.62 \\
-0.84\end{array}$ & $\begin{array}{l}-0.80 \\
-0.74\end{array}$ & $\begin{array}{l}-0.87 \\
-0.70\end{array}$ & $\begin{array}{l}-0.73 \\
-0.87\end{array}$ & $\begin{array}{l}-0.57 \\
-0.84\end{array}$ \\
\hline 2 & $\begin{array}{l}1 \\
2\end{array}$ & $\begin{array}{l}-1.42(8) \\
-1.69(8)\end{array}$ & $\begin{array}{l}-1.41(8) \\
-1.60(8)\end{array}$ & $\begin{array}{l}-1.54(8) \\
-1.66(8)\end{array}$ & $*$ & $\begin{array}{l}-1.51 \\
-2.05\end{array}$ & $\begin{array}{l}-1.19 \\
-1.72\end{array}$ & $\begin{array}{l}-1.17 \\
-1.87\end{array}$ & $\begin{array}{l}-1.23 \\
-1.85\end{array}$ & $\begin{array}{l}-2.00 \\
-1.85\end{array}$ & $\begin{array}{l}-1.60 \\
-2.27\end{array}$ & -1.95 \\
\hline $3^{a}$ & $\begin{array}{l}1 \\
2\end{array}$ & $\begin{array}{l}-1.24(11) \\
-1.03(11)\end{array}$ & $\begin{array}{l}-1.02(11) \\
-1.07(11)\end{array}$ & $\begin{array}{l}-0.98(11) \\
-0.90(11)\end{array}$ & * & $\begin{array}{l}-1.12 \\
-0.88\end{array}$ & $\begin{array}{l}-0.31 \\
-0.30\end{array}$ & $\begin{array}{l}-1.30 \\
-0.94\end{array}$ & $\begin{array}{l}-0.82 \\
-0.83\end{array}$ & $\begin{array}{l}-0.96 \\
-0.88\end{array}$ & $\begin{array}{l}-1.03 \\
-1.18\end{array}$ & $\begin{array}{l}-1.41 \\
-1.17\end{array}$ \\
\hline $3^{b}$ & $\begin{array}{l}1 \\
2\end{array}$ & $\begin{array}{l}-1.53(11) \\
-1.65(11)\end{array}$ & $\begin{array}{l}-1.48(11) \\
-1.70(11)\end{array}$ & $\begin{array}{l}-1.84(11) \\
-1.88(11)\end{array}$ & $*$ & $\begin{array}{l}-1.70 \\
-1.12\end{array}$ & * & -2.08 & $\begin{array}{l}-1.57 \\
-1.70\end{array}$ & $\begin{array}{l}-1.29 \\
-1.67\end{array}$ & $\begin{array}{l}-0.74 \\
-1.04\end{array}$ & $\begin{array}{l}-2.59 \\
-1.85\end{array}$ \\
\hline 4 & $\begin{array}{l}1 \\
2\end{array}$ & $\begin{array}{l}-1.08(7) \\
-1.01(13)\end{array}$ & $\begin{array}{l}-1.08(6) \\
-1.04(13)\end{array}$ & $\begin{array}{l}-1.49(7) \\
-1.48(7)\end{array}$ & * & $\begin{array}{l}-1.48 \\
-1.23\end{array}$ & $\begin{array}{l}-1.29 \\
-1.47\end{array}$ & * -1.43 & $\begin{array}{l}-1.33 \\
-1.31\end{array}$ & $\begin{array}{l}-1.14 \\
-1.22\end{array}$ & $\begin{array}{l}-1.36 \\
-1.25\end{array}$ & -1.36 \\
\hline 5 & $\begin{array}{l}1 \\
2\end{array}$ & $\begin{array}{l}-0.80(10) \\
-0.87(10)\end{array}$ & $\begin{array}{l}-0.81(10) \\
-0.89(10)\end{array}$ & $\begin{array}{l}-0.87(9) \\
-0.93(9)\end{array}$ & $*$ & $\begin{array}{l}-0.82 \\
-0.87\end{array}$ & $\begin{array}{l}-0.79 \\
-0.82\end{array}$ & $\begin{array}{l}-0.77 \\
-0.79\end{array}$ & $\begin{array}{l}-0.78 \\
-0.80\end{array}$ & $\begin{array}{l}-0.78 \\
-0.86\end{array}$ & $\begin{array}{l}-0.84 \\
-0.87\end{array}$ & $\begin{array}{l}-0.66 \\
-0.78\end{array}$ \\
\hline 6 & $\begin{array}{l}1 \\
2\end{array}$ & $\begin{array}{l}-1.42(7) \\
-1.56(7)\end{array}$ & $\begin{array}{l}-1.48(7) \\
-1.54(7)\end{array}$ & $\begin{array}{l}-1.41(7) \\
-1.44(7)\end{array}$ & $*$ & $*$ & $\begin{array}{l}\text { Plas } \\
-1.22\end{array}$ & $\begin{array}{l}\text { ma sampl } \\
-1.30\end{array}$ & $\begin{array}{l}\text { les not ex } \\
-1.23\end{array}$ & amined & $*$ & -1.42 \\
\hline
\end{tabular}

* Slopes not estimable: either one dilution was examined or counts bound (corrected for non-specific binding) were outside the range $10 \%-90 \%$ of maximum binding

a Antiserum A; ${ }^{b}$ Antiserum B

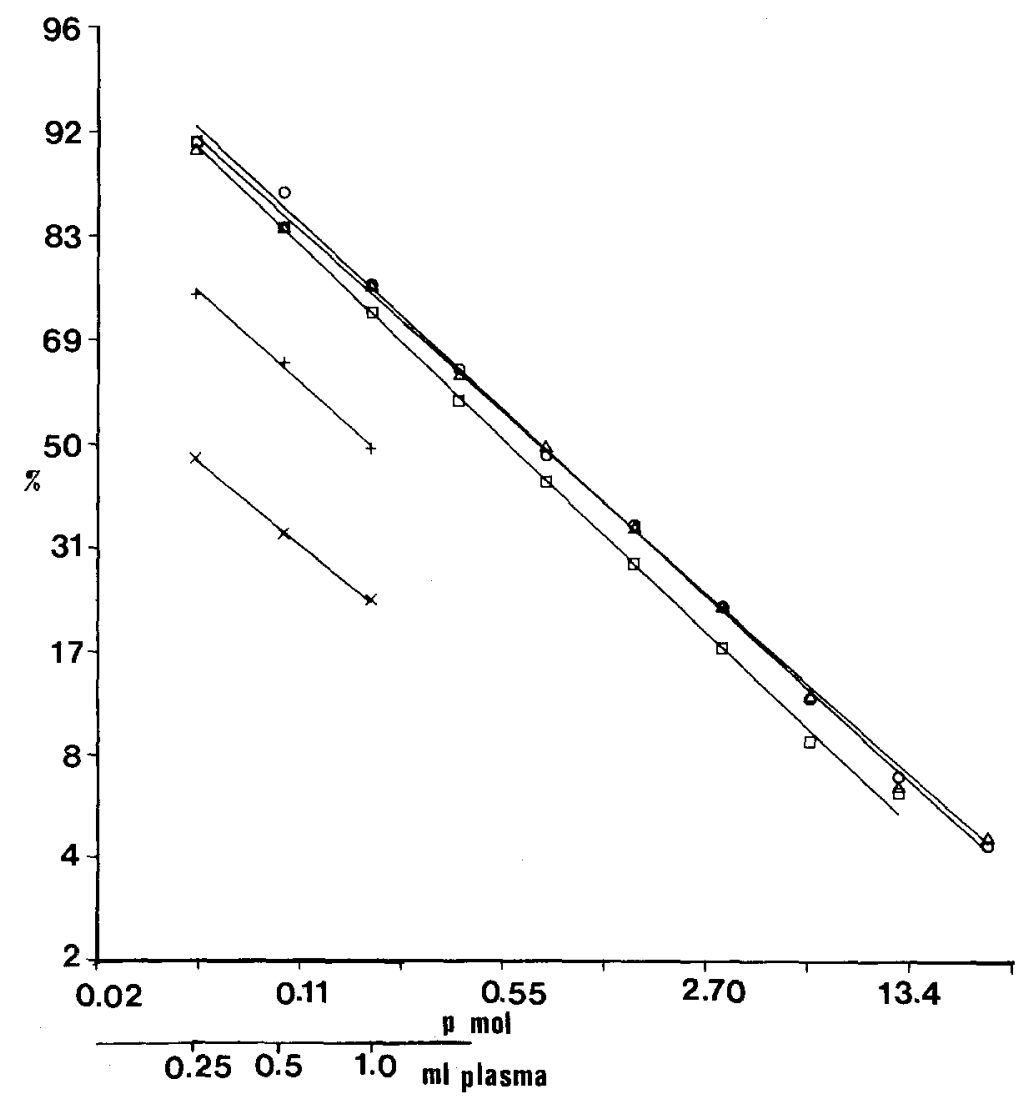

Fig. 1. Fitted dose-response lines and mean observed responses from Assay 2, Laboratory 5 for the Research Standard $\triangle$, the preparation coded A (identical to the Research Standard) $\bigcirc$, the local standard $\square$, and plasma samples $B \times$ and $Z+$. Dose (abscissa) is expressed as $\mathrm{pmol} / \mathrm{ml}$ of the three standard preparations or as ml of plasma sample on a logarithmic scale and response (ordinate) is counts bound expressed as percent of maximum binding corrected for nonspecific binding on a logit scale 


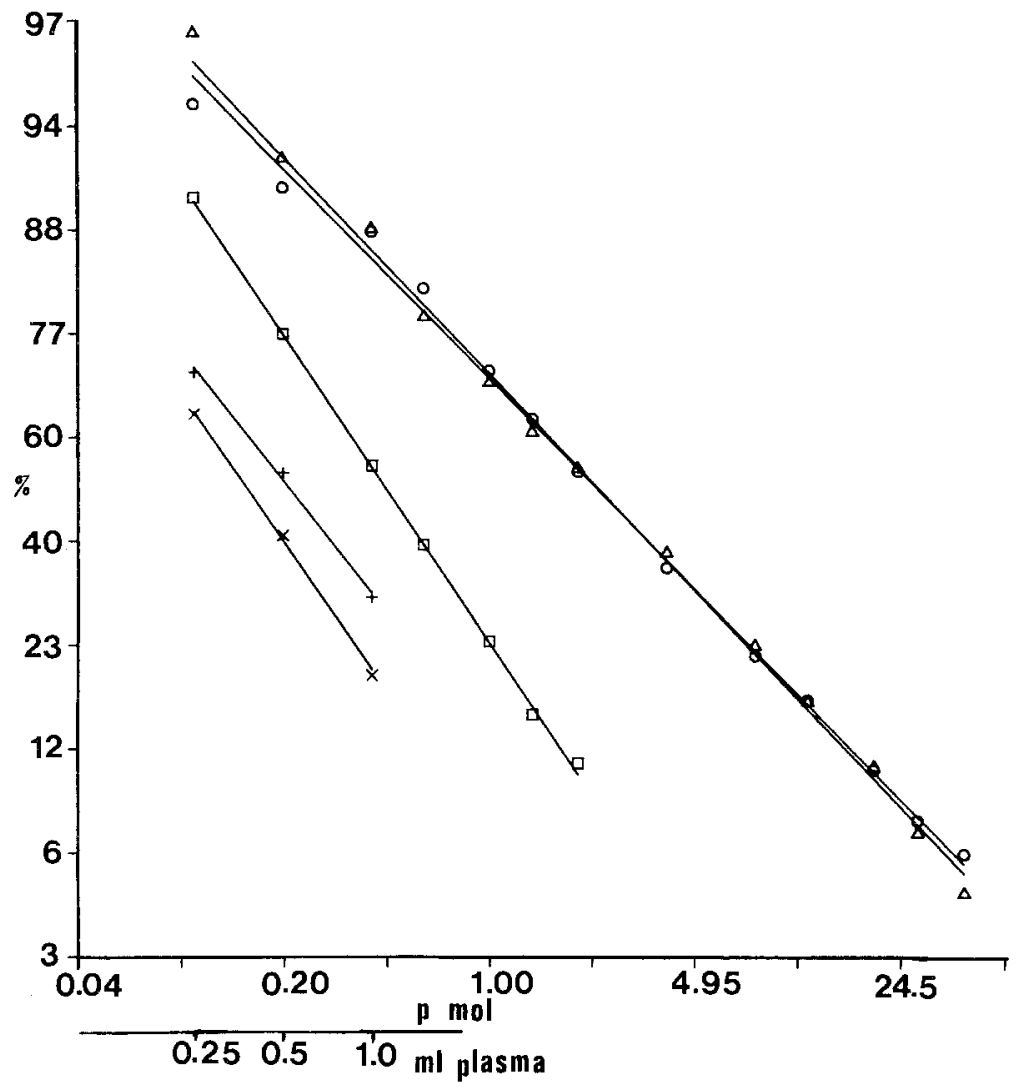

Fig. 2. Fitted dose-response lines and mean observed responses from Assay 2, Laboratory 4 for the Research Standard $\triangle$, the preparation coded A (identical to the Research Standard) $O$, the local standard $\square$, and plasma samples $B \times$ and $Z+$. Dose (abscissa) is expressed as $\mathrm{pmol} / \mathrm{ml}$ of the three standard preparations or as $\mathrm{ml}$ of plasma sample on a logarithmic scale and response (ordinate) is counts bound expressed as percent of maximum binding corrected for nonspecific binding on a logit scale slope for the plasma preparations were less reliable than estimates of slope for the Research Standard, preparation $\mathrm{A}$ or the local standard and this has been taken into account for the statistical comparisons. Comparison of the slopes of the standard preparations and the plasmas showed no statisically significant departures from parallelism in Laboratories 1,5 and 6. Figure 1 shows a plot typical of these assays. In Laboratory 2 there was a tendency, especially in the second assay, for the dose response lines of the plasma samples to be steeper than those of the Research Standard or the local standard (Table 3). In Laboratories 3 and 4 the slopes of the dose response lines for the plasma samples differed from those of the standards but did not follow any consistent pattern. Figure 2 shows a plot typical of these assays.

\section{Variability of Estimates}

Estimates of variability based on replication at each dose often underestimate the within-assay variability [8]. The $95 \%$ confidence intervals for estimates for $\mathrm{A}$ (taken to be $100 \%$ ) based on variability among repli- cates at each dose ranged from $91 \%-110 \%$ to $98 \%-102 \%$, the majority being approximately $96 \%-105 \%$. The two identical preparations, the Research Standard and A, were included in each assay to permit estimation of within assay variation based on the deviation from $100 \%$ of the estimate of A relative to the Research Standard (Table 4), in addition to the estimates of within-assay variation based on replication of responses at each dose. The $95 \%$ confidence interval for an estimate of A based on this estimate of within-assay variability was $83 \%-120 \%$.

Between assay variation was computed for each preparation which was examined in two assays in several laboratories and compared with between laboratory variation. Laboratory 2 has been omitted from these computations, having reported difficulty in dissolving the contents of the vials containing the Research Standard and $\mathrm{A}$ in their first asssay which led to different results between the first and second assays. For all comparisons except for estimates of A in terms of the Research Standard there was significantly greater variation among laboratories than between assays within laboratories. 
Table 4. Estimates of insulin C-peptide content for the standard preparations. (Research Standard 76/561 assumed to contain $2.5 \mathrm{nmol}$ C-peptide)

\begin{tabular}{|c|c|c|c|c|c|}
\hline \multirow[t]{2}{*}{ Laboratory } & \multirow[t]{2}{*}{ Assay } & \multicolumn{2}{|c|}{$\begin{array}{l}\text { Insulin C-peptide in } \\
\text { A as \% of Research } \\
\text { Standard (76/561) }\end{array}$} & \multicolumn{2}{|c|}{$\begin{array}{l}\text { Moles Research } \\
\text { Standard }(76 / 561) \\
\text { per mole local } \\
\text { standard }\end{array}$} \\
\hline & & & $\begin{array}{l}\text { Laboratory } \\
\text { Mean }\end{array}$ & & $\begin{array}{l}\text { Laboratory } \\
\text { Mean }\end{array}$ \\
\hline 1 & $\begin{array}{l}1 \\
2\end{array}$ & $\begin{array}{l}109 \\
104\end{array}$ & 106 & $\begin{array}{l}0.87 \\
0.72\end{array}$ & 0.79 \\
\hline 2 & $\begin{array}{l}1 \\
2\end{array}$ & $\begin{array}{l}112 \\
108\end{array}$ & 110 & $\begin{array}{l}2.04 \\
1.28\end{array}$ & 1.62 \\
\hline $\begin{array}{l}3 \\
\text { (Antiserum A) }\end{array}$ & $\begin{array}{l}1 \\
2\end{array}$ & $\begin{array}{l}111 \\
118\end{array}$ & 114 & $\begin{array}{l}0.90 \\
0.99\end{array}$ & 0.94 \\
\hline $\begin{array}{l}3 \\
\text { (Antiserum B) }\end{array}$ & $\begin{array}{l}1 \\
2\end{array}$ & $\begin{array}{l}108 \\
112\end{array}$ & 110 & $\begin{array}{l}1.50 \\
1.80\end{array}$ & 1.65 \\
\hline 4 & $\begin{array}{l}1 \\
2\end{array}$ & $\begin{array}{l}98 \\
99\end{array}$ & 98 & $\begin{array}{l}3.51 \\
4.01\end{array}$ & 3.75 \\
\hline 5 & $\begin{array}{l}1 \\
2\end{array}$ & $\begin{array}{r}111 \\
97\end{array}$ & 104 & $\begin{array}{l}1.49 \\
1.23\end{array}$ & 1.35 \\
\hline 6 & $\begin{array}{l}1 \\
2\end{array}$ & $\begin{array}{l}86 \\
94\end{array}$ & 90 & $\begin{array}{l}1.48 \\
1.47\end{array}$ & 1.48 \\
\hline
\end{tabular}

Comparison of the Research Standard with Various Local Standards

Comparisons of the Research Standard with the various local standards (Table 4) have been expressed as moles of the Research Standard equivalent to 1 mole of the local standard with 1 ampoule of the Research Standard assumed to contain $2.5 \mathrm{nmol}$ insulin C-peptide. The results vary, as expected, since several different preparations have been used as local standards.

\section{Comparison of Estimates of Insulin C-peptide in the Plasma Samples}

Estimates of the insulin C-peptide content of the plasma samples have been expressed as pmol of the Research Standard per ml of plasma (Table 5), with one ampoule of Research Standard assumed to contain $2.5 \mathrm{nmol}$ of C-peptide.

Numerical estimates of C-peptide content for each of the plasma samples varied significantly among the seven assay systems. Confidence intervals $(\mathrm{p}=0.95)$ about the geometric mean from all systems of the estimated insulin C-peptide per ml plasma (taken to be $100 \%$ ) were $67 \%$ to $149 \%$ for samples X, B, T, M, Z, F and $54 \%$ to $187 \%$ for sample R (Table 5). Estimates for sample $H$ were more variable.

Although the numerical values of the estimates varied, the ranking order was remarkably consistent in these seven assay systems. Without exception plasma $\mathrm{H}$ (from a patient with long-standing diabetes) was estimated to contain little, if any, insulin C-peptide, and plasma F (proinsulin-rich plasma) was estimated to contain a higher concentration of insulin C-peptide than any of the other plasma samples. Estimates for the three related plasmas, B, M and $\mathrm{T}$, were ranked in the same order for insulin $\mathrm{C}$ peptide concentration in each system. Plasma samples $\mathrm{Z}$ and $\mathrm{X}$ were generally consistently ordered second and sixth (exceptions were $\mathrm{Z}$ in Laboratory 3 using Antiserum $B$ and $X$ in Laboratory 3 using Antiserum $\mathrm{A}$ and in Laboratory 4). Plasma sample R (from a patient aged 45 recovering from ketoacidosis) was least consistently ordered, being one of the smallest estimates in Laboratory 6 and one of the largest in Laboratory 3 with Antiserum A (a 6-fold difference).

Examination of the numerical magnitude of the estimates (Table 5) revealed that for any given plasma sample the smallest estimates tended to come from Laboratory 1 or 4 . Laboratories 3 (using Antiserum A), 6 and 5 tended to give intermediate values in that order and the largest estimates tended to come from Laboratory 3 (using Antiserum B) or 2. Thus comparison of the various plasmas with one another gave estimates for one plasma in terms of another which were more homogeneous between laboratories than estimates in terms of the common standard. The confidence interval for the overall geometric mean of $\mathrm{ml}$ of $\mathrm{B}$ equivalent to $1.0 \mathrm{ml}$ of $\mathrm{F}$, for example, was $88 \%$ to $113 \%$. Other comparisons are given in Table 6 .

\section{Estimated Insulin Content of the Plasma Samples}

A radioimmunoassay for insulin carried out in Laboratory 6 gave the following estimated concentrations ( $\mu U$ of the 1st International Reference Preparation of Human Insulin per ampoule) of insulin for the plasma samples:

$\begin{array}{llllllll}\mathrm{H} & \mathrm{R} & \mathrm{X} & \mathrm{B} & \mathrm{T} & \mathrm{M} & \mathrm{Z} & \mathrm{F} \\ 308 & 563 & 48 & 40 & 20 & 8 & 16 & 73\end{array}$

Values for samples $\mathrm{X}, \mathrm{B}$ and $\mathrm{M}$ were of the same order as reported estimates for such subjects [9] and values for $H, R, Z$ and $F$ were consistent with the subjects' clinical condition.

\section{Discussion}

Estimates of C-peptide concentration in the eight plasma samples examined in this study showed numerical heterogeneity between laboratories in terms 
Table 5. Estimated insulin C-peptide content of plasma samples expressed as pmol $(\mathrm{ng} \times 0.25)$ of Research Standard $(76 / 561)$ per $\mathrm{ml}$ of plasma

\begin{tabular}{|c|c|c|c|c|c|c|c|c|}
\hline \multirow[b]{2}{*}{ Laboratory } & \multicolumn{8}{|c|}{ Plasma sample } \\
\hline & $\mathrm{Z}$ & $\mathrm{F}$ & $\mathrm{H}$ & $\mathrm{R}$ & $\mathrm{X}$ & $\mathbf{M}$ & B & $\mathrm{T}$ \\
\hline 1 & 0.32 & 2.24 & 0.05 & 1.07 & 1.21 & 0.41 & 1.44 & 0.79 \\
\hline 2 & 0.72 & 5.72 & 0.08 & 2.81 & 3.60 & 0.96 & 5.02 & 2.38 \\
\hline 3 & & & & & & & & \\
\hline $\begin{array}{l}\text { (Antiserum A) } \\
3\end{array}$ & 0.52 & 3.69 & 0.13 & 1.98 & 1.40 & 0.61 & 2.27 & 1.42 \\
\hline (Antiserum B) & 1.09 & 6.04 & 0.48 & 3.47 & 3.53 & 1.02 & 3.96 & 2.50 \\
\hline 4 & 0.30 & 2.55 & 0.03 & 0.88 & 2.07 & 0.39 & 1.87 & 1.00 \\
\hline 5 & 0.75 & 4.95 & 0.11 & 2.51 & 2.73 & 0.94 & 3.26 & 1.82 \\
\hline 6 & 0.57 & 3.94 & 0.03 & 0.57 & 2.68 & 0.84 & 3.20 & 1.70 \\
\hline Geometric Mean & 0.56 & 3.92 & 0.08 & 1.59 & 2.29 & 0.69 & 2.78 & 1.54 \\
\hline \multicolumn{9}{|c|}{$95 \%$ Confidence interval ( $\%$ of Mean) } \\
\hline Lower limit & $65 \%$ & $70 \%$ & $41 \%$ & $54 \%$ & $67 \%$ & $68 \%$ & $67 \%$ & $67 \%$ \\
\hline Upper limit & $153 \%$ & $143 \%$ & $243 \%$ & $187 \%$ & $149 \%$ & $146 \%$ & $150 \%$ & $148 \%$ \\
\hline
\end{tabular}

of both the Research Standard and the local standards although the variability of estimates in terms of the Research Standard was marginally less. However, the ranking order of the estimates was remarkably consistent between laboratories and use of a related or similar plasma sample as reference preparation led to a striking reduction in variability of estimates between laboratories (Table 6 compared with Table 5).

Although a common standard is necessary if results from one laboratory, or time, to another are to be validly compared, a common standard alone is not sufficient to give comparable results between assay systems of different specificity [10]. Plasma samples are likely to contain immunoreactive materials other than the hormone of interest. Kuzuya et al [11] using two antisera (one to a mixture of human proinsulin and its intermediate forms and one to a synthetic preparation of human proinsulin 31-65) concluded that circulating $\mathrm{C}$-peptide may be heterogeneous. Heding and Rasmussen [2] have discussed the interference by circulating antibodies to insulin with the measurement of immunoreactive C-peptide and also comment on possible immunoreactive products of C-peptide degradation. The observed differences between estimates in the present study are due at least in part to differences in assay system specificity. Comparison of the estimates of C-peptide concentration in the plasma samples for Laboratories 5 and 6 (Table 5), for example, shows good agreement for samples $\mathrm{X}, \mathrm{M}, \mathrm{B}$ and $\mathrm{T}$ (from healthy subjects) while samples $Z$ and $F$ (from patients with insulinoma) differ by $30 \%$ in the two laboratories and samples $\mathrm{H}$ and $\mathrm{R}$ (from patients with diabetes) by more than $300 \%$. Comparison of results from Laboratory 3 using antiserum A or B
Table 6. Estimated insulin C-peptide content/ml of plasma samples $B, T$ and $R$ expressed as ml-equivalents of plasma sample $M$, and per $\mathrm{ml}$ of plasma sample $\mathrm{B}$ expressed as ml-equivalents of plasma sample X. For comparison with Table 4 the estimated Cpeptide content per $\mathrm{ml}$ of plasma sample $\mathrm{B}$ has been expressed as pmol of local house standard for each laboratory. Plasma samples $\mathrm{M}$ and $\mathbf{B}$ were from the same subject fasted overnight and $1.5 \mathrm{~h}$ after glucose load respectively and sample $\mathrm{T}$ a mixture of equal parts $\mathrm{M}$ and $\mathrm{B}$. Plasma sample $\mathrm{X}$ was from a pool from four subjects $1.5 \mathrm{~h}$ after glucose load. Plasma sample $\mathrm{R}$ was from a patient with diabetes recovering from severe ketoacidosis

\begin{tabular}{|c|c|c|c|c|c|}
\hline \multirow[b]{2}{*}{ Laboratory } & \multicolumn{5}{|c|}{ Plasma sample } \\
\hline & $\begin{array}{l}\mathrm{B} \\
(\mathrm{ml} . \mathrm{M})\end{array}$ & $\begin{array}{l}\mathrm{T} \\
\text { (ml. M) }\end{array}$ & $\begin{array}{l}\text { R } \\
\text { (ml. M) }\end{array}$ & $\begin{array}{l}\mathrm{B} \\
(\mathrm{ml} . \mathrm{X})\end{array}$ & $\begin{array}{l}\text { B } \\
\text { pmol }\end{array}$ \\
\hline 1 & 3.52 & 1.93 & 2.61 & 1.18 & 1.82 \\
\hline 2 & 5.24 & 2.48 & 2.93 & 1.39 & 3.09 \\
\hline 3 & & & & & \\
\hline $\begin{array}{l}\text { (Antiserum A) } \\
3\end{array}$ & 3.72 & 2.33 & 3.25 & 1.62 & 2.44 \\
\hline (Antiserum B) & 3.88 & 2.45 & 3.40 & 1.12 & 2.37 \\
\hline 4 & 4.85 & 2.58 & 2.26 & 0.91 & 0.50 \\
\hline 5 & 3.47 & 1.93 & 2.67 & 1.19 & 2.41 \\
\hline 6 & 3.82 & 2.03 & 0.68 & 1.20 & 2.42 \\
\hline Geometric Mean & 4.03 & 2.23 & 2.31 & 1.21 & 1.92 \\
\hline \multicolumn{6}{|c|}{$95 \%$ Confidence interval ( $\%$ of Mean) } \\
\hline Lower limit & $86 \%$ & $89 \%$ & $60 \%$ & $85 \%$ & $57 \%$ \\
\hline Upper limit & $116 \%$ & $112 \%$ & $167 \%$ & $119 \%$ & $176 \%$ \\
\hline
\end{tabular}

shows a consistent pattern with antiserum A giving estimates about half those obtained with antiserum B. There is a tendency for the relationship between estimates from different laboratories to be consistent suggesting that a reference plasma may be useful [12]. Nevertheless, the observed differences indicate that clinical interpretation of results from insulin C- 
peptide immunoassays must depend on the characteristics of the specific assay system used.

This study suggests that in the assay systems examined, except for that of Laboratory 4, the Research Standard is no less suitable than existing standards, and generally satisfies the minimum requirement of parallelism with the preparations used (so far as this could be determined). Although significantly different from the slope of the local standard for Laboratory 3 using Antiserum B, the slope of the Research Standard agreed with the slopes obtained with the plasma samples. However, until there is greater uniformity in assay specificity it is unlikely that any single reference material will give the same results with all systems, or that anomalous results like those obtained in the present study for plasma sample $\mathrm{R}$ will be eliminated. Moreover if this synthetic material is used, assay systems in which it is used should be shown not to discriminate between this analogue and the natural C-peptide. Nevertheless, it is agreed that, until a reference preparation consisting of the natural human C-peptide can be provided, the preparation in ampoules coded $76 / 561$, each containing approximately $2.5 \mathrm{nmol}$ of synthetic 64 formyllysine C-peptide of human proinsulin, will be made available for research purposes. However, it should be noted that this preparation may not generally be suitable as a reference preparation for assay of human C-peptide.

Acknowledgements. Grateful acknowledgement is made to all the participants, to Professor N. Yanaihara for provision of the synthetic 64-formyllysine human proinsulin 31-65 for the Research Standard, to Dr. R. Turner of the Radcliffe Infirmary, Oxford, for the proinsulin-rich plasma, to Dr. Becket of the Royal Free Hospital, London, for the diabetic plasma, to Dr. P. J. Campbell, National Institute for Biological Standards for preparation of the various materials in ampoules and to Miss M. V. Mussett and the referees for helpful comments.

\section{References}

1. Block MB, Mako ME, Steiner DF, Rubenstein AH (1972) Circulating C-peptide immunoreactivity. Studies in normal and diabetic patients. Diabetes 21: 1013-1026

2. Heding L G, Rasmussen SM (1975) Human C-peptide in normal and diabetic subjects. Diabetologia 11: 201-206

3. Heding L G, Turner R C, Harris E (1975) C-peptide, proinsulin and insulin responses to fish-insulin induced hypoglycaemia in the diagnosis of insulinomas. Diabetes 24 [Suppl 2]: 412

4. Horwitz DL, Starr J I, Mako ME, Blackard W G, Rubenstein AH (1975) Proinsulin, insulin and C-peptide concentrations in human portal and peripheral blood. J Clin Invest 55: $1278-1283$

5. Kuzuya T, Matsuda A, Saito T, Yoshida S (1976) Human Cpeptide immunoreactivity (CPR) in blood and urine: Evaluation of a radio-immunoassay method and its clinical applications. Diabetologia 12: 511-518

6. Caygill CP J (1977) Detection of peptidase activity in albumin preparations. Clin Chim Acta 78: 507-509

7. Gaines Das RE, Cotes P M (1978) Calibration of replacement standards for radioimmunoassay: A method for comparison of dose-response curves given by several preparations in a single assay. J Endocrinol 77: 31P-32P

8. Finney DJ, Gaines Das RE (In press) In: The 8th Tenovus Workshop: Quality control in clinical endocrinology. Wilson DW, Gaskell S J, Kemp KW (eds). Alpha Omega Publishing Ltd, Cardiff

9. Perley M, Kipnis DM (1966) Plasma insulin responses to glucose and tolbutamide of normal weight and obese diabetics and nondiabetic subjects. Diabetes 15: 867-874

10. Bangham DR (1976) Standardization in peptide hormone immunoassays: Principle and practice. Clin Chem 22: 957-963

11. Kuzuya H, Blix PM, Horwitz D L, Rubenstein AH, Steiner DF, Binder C, Faber OK (1977) Heterogeneity of circulating C-peptide. J Clin Endocrinol Metab 44: 952-962

12. Gaines-Das RE (1978) Estimation and correction of bias in potency estimates from radioimmunoassay by use of a reference material. J Biol Stand 6: 289-299

Received: April 6, 1979,

and in revised form: October 26,1979

Dr. Rose E. Gaines Das

National Institute for Biological Standards and Control

Hampstead

London NW3 6RB, England 